Supporting Information

\title{
Hydrogen Sulfide-Responsive Self-Assembled Nanogel
}

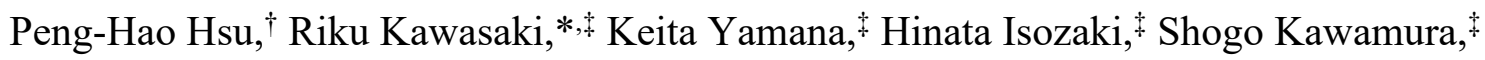
Atsushi Ikeda, ${ }^{\star}$ Adah Almutairi*,§

†Department of Chemistry and Biochemistry, University of California San Diego, 9500 Gilman Dr., La Jolla, California 92093, United States, \$Program of Applied Chemistry, Graduate School of Advanced Science and Engineering, Hiroshima University, 1-4-1 Kagamiyama, HigashiHiroshima 739-8527, Japan, and \$Skaggs School of Pharmacy and Pharmaceutical Sciences, University of California San Diego, 9500 Gilman Dr., La Jolla, California 92093, United States

*E-mail: aalmutairi@ucsd.edu

*E-mail: riku0528@hiroshima-u.ac.jp

\section{General methods and instrumentation}

All the reagents and solvents were purchased from commercial sources and used without further purification unless otherwise indicated. Silica gel flash column chromatography was performed on an automated CombiFlash ${ }^{\circledR}$ Rf 200 system with RediSep Rf prepacked silica columns. Nuclear magnetic resonance (NMR) spectra were obtained on a Varian spectrometer (600 MHz). Chemical shifts $(\delta)$ are given in parts per million (ppm) relative to internal standards: $\mathrm{CHCl}_{3}\left(\delta_{\mathrm{H}}=7.26\right)$, $\mathrm{CDCl}_{3}\left(\delta_{\mathrm{C}}=77.0\right.$ for the central line of triplet $)$ and $\left(\mathrm{CH}_{3}\right)_{2} \mathrm{SO}\left(\delta_{\mathrm{H}}=2.50\right)$. The splitting patterns are reported as s (singlet), d (doublet), t (triplet), m (multiplet), dd (double of doublets) and br (broad). Coupling constants $(J)$ are given in Hz. The ESI-MS experiments for compound characterization were conducted on an Agilent 6230 ESI-TOFMS high-resolution mass spectrometer. Nanogels were formulated by sonication (Misonix Sonicator, S-4000). DLS analyses and zeta potential measurement were conducted on a Malvern Zetasizer Nano ZS. TEM observations were carried out on a JEOL JEM-2010. Fluorescence measurements were conducted on a Horiba Jobin Yvon Fluorolog and a Hitachi F-2700 fluorescence spectrophotometer. Ultracentrifugation was performed on a Hitachi himac CS120GXII micro ultracentrifuge. 


\section{Abbreviations}

$\mathrm{SC}$-Dex $=\mathrm{H}_{2} \mathrm{~S}$-responsive cholesterol-modified dextran, CBS = cystathionine $\beta$-synthase, $\mathrm{CSE}=$ cystathionine $\gamma$-lyase, $\mathrm{CHP}=$ cholesterol-modified pullulan, $\mathrm{DCM}=$ dichloromethane, DMAP = 4-dimethylaminopyridine, $\mathrm{THF}=$ tetrahydrofuran, $\mathrm{DMSO}=$ dimethyl sulfoxide, $\mathrm{DMF}=$ dimethylformamide, $\mathrm{TBDPSCl}=$ tert-butylchlorodiphenylsilane, TBAF $=$ tetrabutylammonium fluoride, $\mathrm{CDI}=1,1^{\prime}$-carbonyldiimidazole, $\mathrm{NMR}=$ nuclear magnetic resonance, $\mathrm{TEM}=$ transmission electron microscopy, $\mathrm{NG}=$ nanogel, DLS = dynamic light scattering, $\mathrm{GSH}=$ glutathione, FITC-BSA = fluorescein isothiocyanate labelled bovine serum albumin, $\mathrm{RhB}=$ rhodamine B.

\section{Synthesis of SC-Dex}

\section{Compound 1}

Compound 1 was prepared according to previously reported procedure. The spectral data was in agreement with previously reported data.

\section{Compound 2}

Compound 1 (165.0 mg, $0.92 \mathrm{mmol}$ ) and imidazole (99.7 mg, $1.46 \mathrm{mmol}$ ) were dissolved in DMF $(5 \mathrm{~mL})$ and added the solution of TBDPSCl $(211.7 \mathrm{mg}, 0.77 \mathrm{mmol})$ in DMF $(10 \mathrm{~mL})$ dropwise over $1 \mathrm{~h}$. The reaction mixture was further stirred at room temperature for $4 \mathrm{~h}$ and then partitioned between EtOAc and brine. The organic layer was washed with brine three times, dried over $\mathrm{MgSO}_{4}$, filtered and purified by silica gel chromatography $(100 \%$ hexane to EtOAc/hexane $=7: 3)$ to afford compound 2 (113.5 mg, 35\%).

$\mathrm{C}_{24} \mathrm{H}_{27} \mathrm{~N}_{3} \mathrm{O}_{2} \mathrm{Si} ;{ }^{1} \mathrm{H}$ NMR (600 MHz, $\left.\mathrm{CDCl}_{3}\right) \delta$ 7.75-7.70 (4 H, m), 7.49-7.39 (7 H, m), $7.32(1 \mathrm{H}$, $\mathrm{d}, J=6.0 \mathrm{~Hz}), 7.20(1 \mathrm{H}, \mathrm{t}, J=6.0 \mathrm{~Hz}), 4.88(2 \mathrm{H}, \mathrm{s}), 4.77(2 \mathrm{H}, \mathrm{s}), 2.20(1 \mathrm{H}, \mathrm{br}), 1.13(9 \mathrm{H}, \mathrm{s})$; ${ }^{13} \mathrm{C} \mathrm{NMR}\left(150 \mathrm{MHz}, \mathrm{CDCl}_{3}\right) \delta 135.6,134.9,134.8,134.2,133.2,129.9,128.0,127.9,127.8,125.8$, $62.4,61.6,26.9,19.3$.

\section{Compound 3}

Compound 2 (71.4 mg, $0.17 \mathrm{mmol})$ and cholesteryl chloroformate $(228.6 \mathrm{mg}, 0.51 \mathrm{mmol})$ were dissolved in THF (3 mL). The solution was added DMAP $(6.2 \mathrm{mg}, 0.051 \mathrm{mmol})$ and then pyridine 
$(80 \mu \mathrm{L}, 0.98 \mathrm{mmol})$ slowly. The reaction mixture was stirred at $60{ }^{\circ} \mathrm{C}$ for $3 \mathrm{~h}$, cooled, and concentrated under reduced pressure. The residue was diluted with EtOAc and washed with $\mathrm{H}_{2} \mathrm{O}$ then brine. The organic phase was dried over $\mathrm{MgSO}_{4}$, filtered and purified by silica gel chromatography $(100 \%$ hexane to EtOAc/hexane $=1: 9)$.

The purified intermediate was dissolved in THF $(2 \mathrm{~mL})$ and added TBAF trihydrate (108.4 mg, $0.34 \mathrm{mmol})$. The reaction mixture was stirred at room temperature for $2 \mathrm{~h}$ and then concentrated under reduced pressure. The residue was purified by silica gel chromatography $(100 \%$ hexane to EtOAc/hexane $=3: 7)$ to afford compound 3 as white solid $(79.3 \mathrm{mg}, 76 \%)$.

$\mathrm{C}_{36} \mathrm{H}_{53} \mathrm{~N}_{3} \mathrm{O}_{4} ;{ }^{1} \mathrm{H}$ NMR (600 MHz, $\left.\mathrm{CDCl}_{3}\right) \delta 7.36(1 \mathrm{H}, \mathrm{d}, J=6.0 \mathrm{~Hz}), 7.33(1 \mathrm{H}, \mathrm{d}, J=6.0 \mathrm{~Hz})$, $7.16(1 \mathrm{H}, \mathrm{t}, J=6.0 \mathrm{~Hz}), 5.41-5.36(1 \mathrm{H}, \mathrm{m}), 5.21(2 \mathrm{H}, \mathrm{s}), 4.74(2 \mathrm{H}, \mathrm{s}), 4.52-4.45(1 \mathrm{H}, \mathrm{m}), 2.67$

(1 H, br), 2.44-2.32 (2 H, m), 2.04-1.90 (3 H, m), 1.90-1.78 (2 H, m), 1.69-0.81 (33 H, m), 0.67 $(3 \mathrm{H}, \mathrm{s}) ;{ }^{13} \mathrm{C} \mathrm{NMR}\left(150 \mathrm{MHz}, \mathrm{CDCl}_{3}\right) \delta 154.3,139.3,136.6,135.0,130.1,129.7,129.2,126.0$, $123.0,78.3,65.7,61.5,56.7,56.2,50.0,42.3,39.6,38.0,36.9,36.5,36.2,35.8,31.9,31.8,28.3$, 28.1, 27.7, 23.9, 22.9, 22.6, 21.1, 19.3, 18.8, 11.9; HRMS (ESI) calcd for $\mathrm{C}_{36} \mathrm{H}_{53} \mathrm{~N}_{3} \mathrm{NaO}_{4}$ : 614.3934, found: $\mathrm{m} / \mathrm{z} 614.3927[\mathrm{M}+\mathrm{Na}]^{+}$.

\section{Compound 4}

Compound 3 (101.5 mg, $0.17 \mathrm{mmol}$ ) was dissolved in DCM (3 mL) and added CDI (82.4 mg, 0.50 mmol). The reaction mixture was stirred at room temperature for $3 \mathrm{~h}$ and then concentrated under reduced pressure. The residue purified by silica gel chromatography $(100 \%$ hexane to EtOAc/hexane $=3: 7)$ to afford compound 4 (122.4 mg, quant.).

$\mathrm{C}_{40} \mathrm{H}_{55} \mathrm{~N}_{5} \mathrm{O}_{5} ;{ }^{1} \mathrm{H}$ NMR (600 MHz, $\left.\mathrm{CDCl}_{3}\right) \delta 8.15$ (1 H, s), 7.51-7.45 (2 H, m), $7.43(1 \mathrm{H}, \mathrm{s}), 7.26$ $(1 \mathrm{H}, \mathrm{t}, J=6.0 \mathrm{~Hz}), 7.06(1 \mathrm{H}, \mathrm{s}), 5.52(2 \mathrm{H}, \mathrm{s}), 5.41-5.36(1 \mathrm{H}, \mathrm{m}), 5.27(2 \mathrm{H}, \mathrm{s}), 4.54-4.47(1 \mathrm{H}$, m), 2.44-2.33 (2 H, m), 2.03-1.91 (3 H, m), 1.90-1.76 (2 H, m), 1.69-0.81 (33 H, m), 0.67 (3 H, s); $\left.{ }^{13} \mathrm{C} \mathrm{NMR} \mathrm{(150} \mathrm{MHz,} \mathrm{CDCl}_{3}\right) \delta 154.0,148.3,139.1,138.1,137.1131 .9,131.8,130.7,130.1$, $128.3,126.2$, 122.9, 117.0, 78.2, 66.0, 65.3, 56.6, 56.0, 49.9, 42.2, 39.6, 39.4, 37.9, 36.4, 36.1, $35.7,31.8,31.7,28.2,27.9,27.5,23.8,22.8,22.5,19.2,18.6,11.8$; HRMS (ESI) calcd for $\mathrm{C}_{40} \mathrm{H}_{56} \mathrm{~N}_{5} \mathrm{O}_{5}$ : 686.4281, found: $\mathrm{m} / \mathrm{z} 686.4280[\mathrm{M}+\mathrm{H}]^{+}$.

\section{SC-Dex}


The solution of dextran (40 kDa, $100 \mathrm{mg}, 0.62 \mathrm{mmol}$ of anhydrous glucose unit) in DMSO (1.988 $\mathrm{mL}$ ) was added the solution of compound 3 in DMSO (562 $\mu \mathrm{L}$ of $33 \mathrm{mM}$ solution, $0.019 \mathrm{mmol})$, the solution of DMAP in DMSO $(350 \mu \mathrm{L}$ of $64 \mathrm{mM}$ solution, $0.022 \mathrm{mmol})$ and pyridine $(100 \mu \mathrm{L})$. The reaction mixture was stirred at $40^{\circ} \mathrm{C}$ for $24 \mathrm{~h}$ and then precipitated out in $\mathrm{Et}_{2} \mathrm{O} / \mathrm{EtOH}(9: 1)$. The precipitate was collected by centrifugation at $20000 \mathrm{rpm}$ at $20{ }^{\circ} \mathrm{C}$ for $10 \mathrm{~min}$ and then redissolved in DMSO. The resulting DMSO solution was dialyzed against $\mathrm{ddH}_{2} \mathrm{O}$ using $3.5 \mathrm{k}$ regenerated cellulose membrane (Spectrum) and lyophilized to afford SC-Dex. The degree of chlosteryl substitution was determined by ${ }^{1} \mathrm{H}$ NMR analysis of SC-Dex in $\mathrm{d}_{6}-\mathrm{DMSO} / \mathrm{D}_{2} \mathrm{O}(9: 1)$.

\section{4. ${ }^{1} \mathrm{H}$ NMR analysis of SC-Dex degradation}

SC-Dex $(5.55 \mathrm{mg})$ was dissolved in $\mathrm{d}_{6}$-DMSO $(1 \mathrm{~mL}) .50 \mu \mathrm{L}$ of deuterated phosphate buffer $(100$ $\mathrm{mM}, \mathrm{pH}$ 7.4) with or without $50 \mathrm{mM}$ of $\mathrm{H}_{2} \mathrm{~S}$ was added into $450 \mu \mathrm{L}$ of SC-Dex solution. The resulting mixture was incubated at $37{ }^{\circ} \mathrm{C} .{ }^{1} \mathrm{H}$ NMR spectra were acquired at different time points.

\section{Nanogel formulation}

SC-Dex was suspended in $\mathrm{ddH}_{2} \mathrm{O}\left(2 \mathrm{mg} \mathrm{mL}^{-1}\right)$. The solution was probe sonicated (S-4000, Misonix Sonicator) for $15 \mathrm{~min}$ in an ice bath and then centrifuged at $13400 \mathrm{rpm}$ for $5 \mathrm{~min}$. The supernatant was passed through a $0.22 \mu \mathrm{m}$ PES syringe filter (Olympus) and lyophilized to afford SC-Dex NGs. DLS and TEM were used to characterize size and size distribution of NGs.

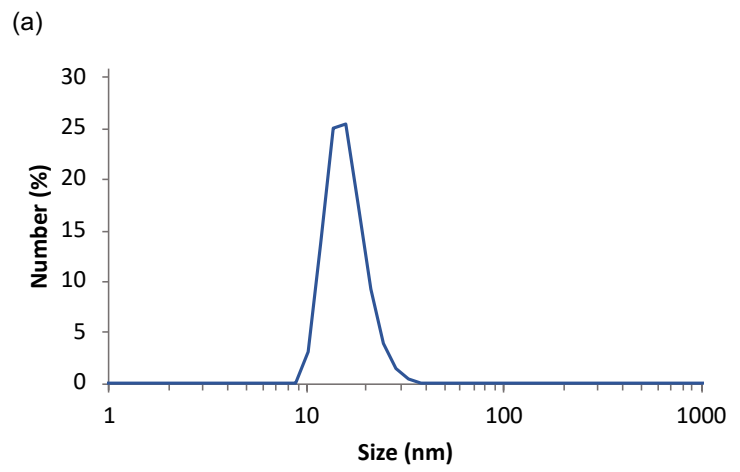

(b)

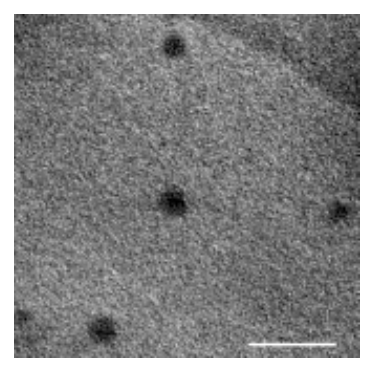

Figure S1. (a) Size distribution of SC-Dex NGs measured by DLS. (b) TEM image of SC-Dex NGs (scale bar $=100 \mathrm{~nm}$ ). 


\section{Detection of hydrophobic nanodomains of SC-Dex NGs}

The pyrene stock solution $\left(1 \times 10^{-4} \mathrm{M}\right)$ was prepared by dissolving pyrene in EtOH. The solution of varying amount of SC-Dex NGs in $\mathrm{ddH}_{2} \mathrm{O}(495 \mu \mathrm{L})$ were added the pyrene stock solution $(5$ $\mu \mathrm{L})$ to give the final pyrene concentration of $1 \times 10^{-6} \mathrm{M}$. The resulting solutions were stirred vigorously for $24 \mathrm{~h}$. The ratio of the emission intensities at $374 \mathrm{~nm}\left(I_{1}\right)$ and $385 \mathrm{~nm}\left(I_{3}\right)$ was plotted against the concentration of SC-Dex NG.

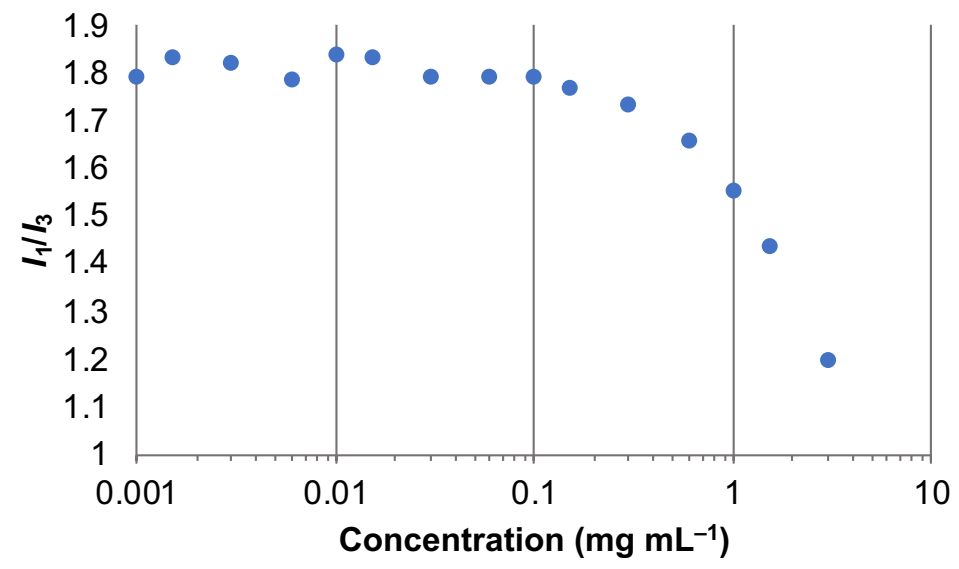

Figure $\mathrm{S} 2 . I_{1} / I_{3}$ ratio of pyrene with varying concentration of SC-Dex NGs in $\mathrm{ddH}_{2} \mathrm{O}$.

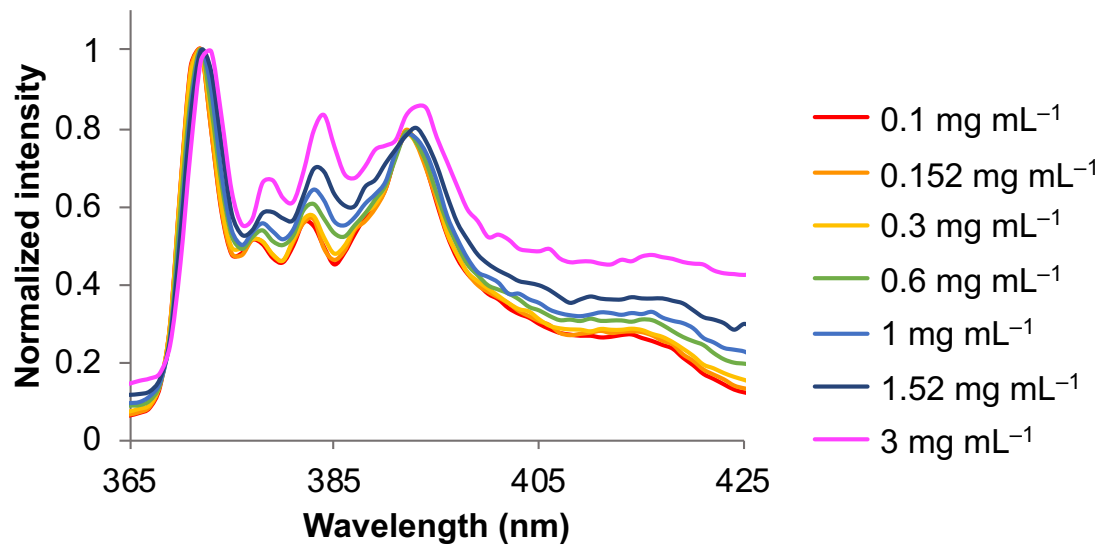

Figure S3. Fluorescence spectra of pyrene with varying concentration of SC-Dex NGs in $\mathrm{ddH}_{2} \mathrm{O}$.

\section{Cytotoxicity studies}

RAW267.4 cells (RIKEN Bio Resource) were seeded on a 96 well plate at the density of 5000 cells per well. After $18 \mathrm{~h}$ incubation at $37^{\circ} \mathrm{C}$, the cells were added varying concentrations of SC- 
Dex NGs in triplicates and incubated at the same condition for another $24 \mathrm{~h}$. The cells were then added cell-counting kit (Dojindo). The cell viability was quantified by measuring the absorbance at $450 \mathrm{~nm}$ using microplate reader.

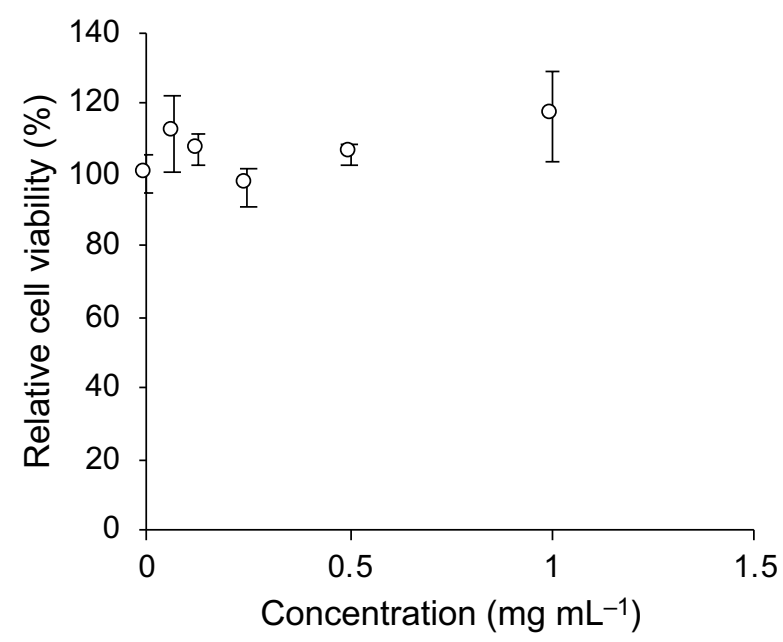

Figure S4. Cell viabilities of RAW267.4 cells after $24 \mathrm{~h}$ incubation with different concentrations of SC-Dex NGs.

\section{Responsiveness study of SC-Dex NGs}

SC-Dex NGs $\left(0.5 \mathrm{mg} \mathrm{mL}^{-1}\right)$ were incubated in $50 \mathrm{mM}$ phosphate buffer (pH 7.4), $50 \mathrm{mM}$ phosphate buffer with $3 \mathrm{mM} \mathrm{H}_{2} \mathrm{~S}$ (pH 7.4) or $50 \mathrm{mM}$ phosphate buffer with $10 \mathrm{mM} \mathrm{GSH} \mathrm{(pH} \mathrm{7.4).}$ at $37^{\circ} \mathrm{C}$, and DLS analyses were performed at different time points. For TEM observation, the NG solution was concentrated and desalted by centrifugation (15 min, $13400 \mathrm{rpm}$ ) using Amicon Ultra-0.5 Centrifugal Filter (10 K, Millipore) after $48 \mathrm{~h}$ of incubation. The concentrated samples were diluted to approximately $1 \mathrm{mg} \mathrm{mL}^{-1}$ using $\mathrm{ddH}_{2} \mathrm{O} .5 \mu \mathrm{L}$ of concentrated sample was dripped on a TEM copper grid, dried under vacuum, stained with $1.5 \%$ ammonium molybdate for $10 \mathrm{sec}$ and imaged by TEM (JEM-2010, JEOL, Japan). 
Supporting Information

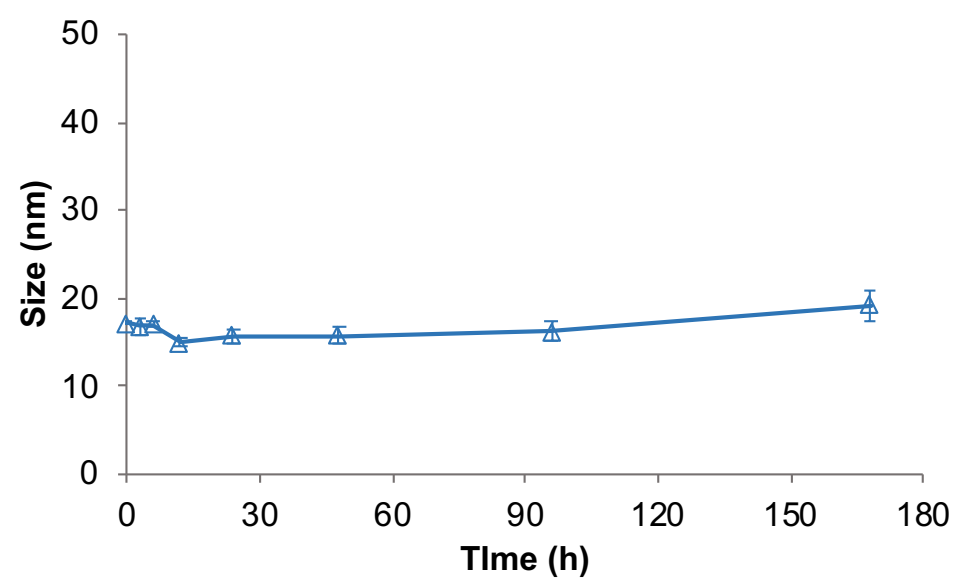

Figure S5. Size change of SC-Dex NGs in $50 \mathrm{mM}$ phosphate buffer ( $\mathrm{pH} 7.4$ ) for 7 days.

(a)

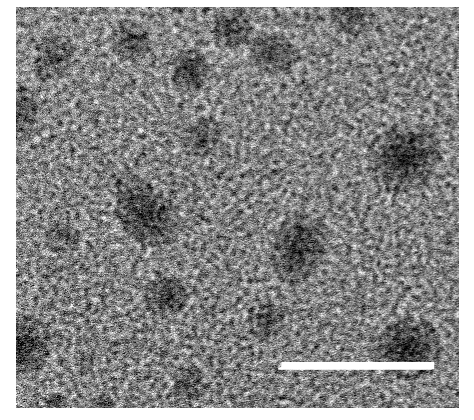

(b)

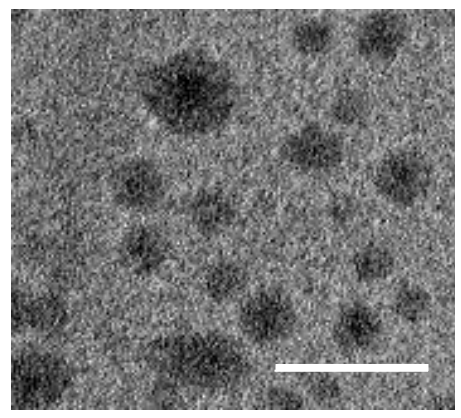

Figure S6. TEM images of SC-Dex NGs after incubation in (a) $50 \mathrm{mM}$ phosphate buffer (pH 7.4) for $48 \mathrm{~h}$ and (b) $50 \mathrm{mM}$ phosphate buffer with $10 \mathrm{mM} \mathrm{GSH}(\mathrm{pH} 7.4)$ for $48 \mathrm{~h}$ (scale bar $=100 \mathrm{~nm}$ ).

\section{Encapsulation of FITC-BSA into RhB-labeled SC-Dex NGs}

FITC-BSA was prepared using BSA (Sigma Aldrich) and FITC labeling kit (DOJINDO). RhBlabeled SC-Dex was prepared following the procedures reported in a previous literature. ${ }^{1} \mathrm{RhB}-$ labeled SC-Dex NGs were formulated following the same procedure stated previously.

RhB-labeled SC-Dex NGs $\left(0.1 \mathrm{mg} \mathrm{mL}^{-1}\right)$ and FITC-BSA $\left(0.01 \mathrm{mg} \mathrm{mL}^{-1}\right)$ were incubated in PBS at $37^{\circ} \mathrm{C}$ for $24 \mathrm{~h}$. The solution was then centrifuged at $120,000 \mathrm{~g}$ and $4{ }^{\circ} \mathrm{C}$ for $90 \mathrm{~min}$ to separate free FITC-BSA from the pellet, NG-protein complexes. The pellet was taken, and its fluorescence spectrum was recorded at an excitation wavelength of $495 \mathrm{~nm}$ to confirm the successful encapsulation of FITC-BSA into RhB-labeled SC-Dex NGs. The size and zeta potential of NGprotein complexes were characterized using Malvern Zetasizer Nano ZS. The complexation ratio 
was calculated to be $50 \%$ by comparing the fluorescence intensity of fed FITC-BSA and free FITC-BSA, indicating that the weight ratio of SC-Dex NG and FITC-BSA within the complex is $20: 1$.

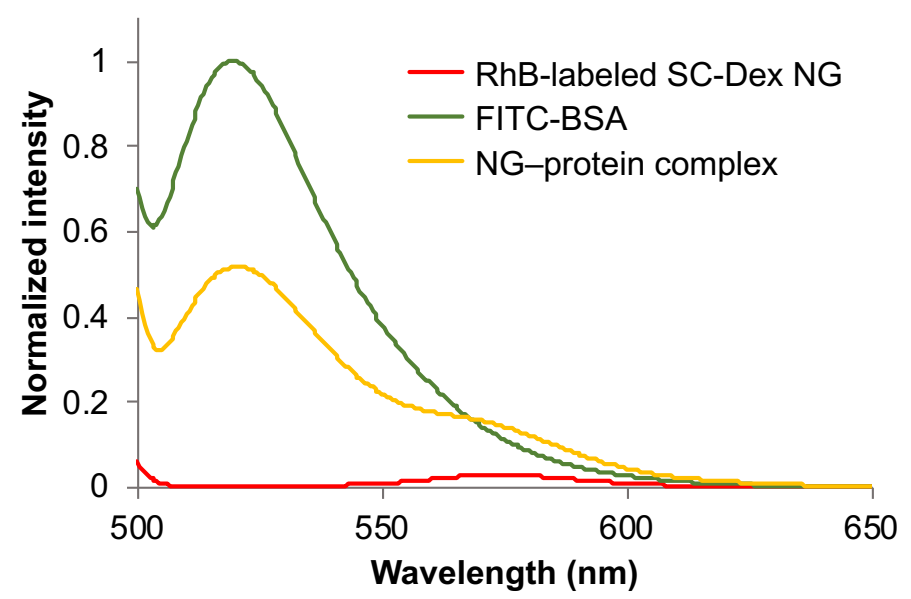

Figure S7. Fluorescence emission spectra of FITC-BSA, RhB-labeled SC-Dex NG and NGprotein complex at an excitation wavelength of $495 \mathrm{~nm}$.

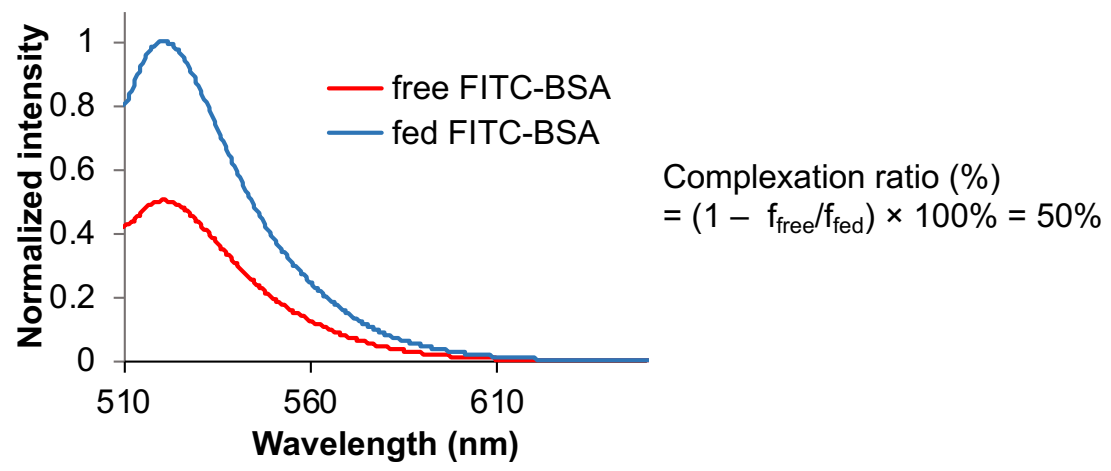

Figure S8. Fluorescence emission spectra of fed FITC-BSA and free FITC-BSA after protein encapsulation.

\section{Release study of FITC-BSA from NG-protein complexes}

NG-protein complexes ( $2 \mathrm{~mL}$; NG, $0.1 \mathrm{mg} \mathrm{mL}^{-1}$; FITC-BSA, $0.005 \mathrm{mg} \mathrm{mL}^{-1}$ ) were incubated in PBS (pH 7.4) or PBS with $3 \mathrm{mM} \mathrm{H}_{2} \mathrm{~S}$ (pH 7.4) at $37^{\circ} \mathrm{C}$. At each time point, the incubation sample was centrifuged at $120,000 \mathrm{~g}$ and $4{ }^{\circ} \mathrm{C}$ for $90 \mathrm{~min}$. The pellet was re-dispersed in the corresponding buffer and incubated at $37^{\circ} \mathrm{C}$ until the next time point. The fluorescence spectra 
Supporting Information

of the supernatants were recorded at an excitation wavelength of $495 \mathrm{~nm}$, and the emission intensity at $520 \mathrm{~nm}$ was used to calculate the amount of released FITC-BSA.

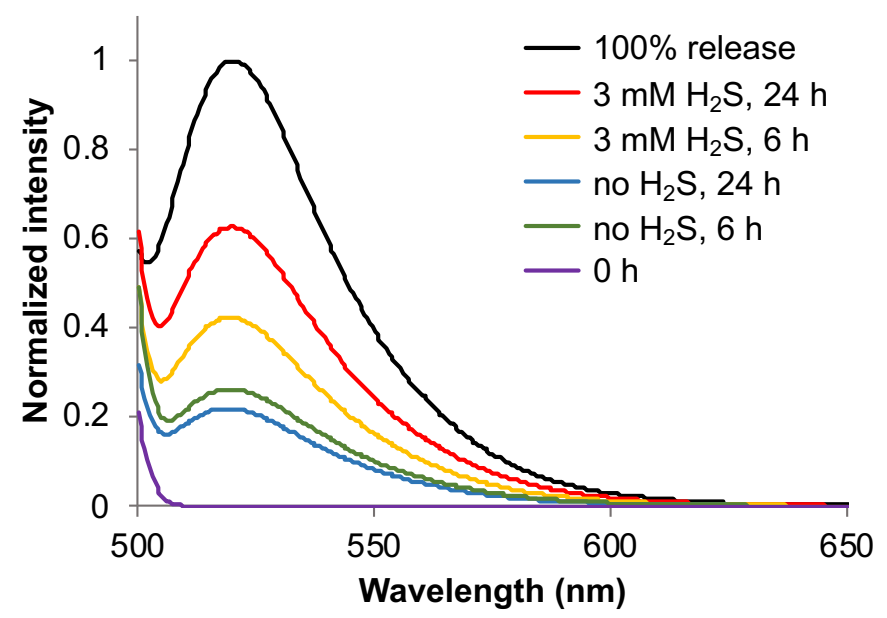

Figure S9. Fluorescence emission spectra of released FITC-BSA from different samples at an excitation wavelength of $495 \mathrm{~nm}$.

\section{NMR spectra}

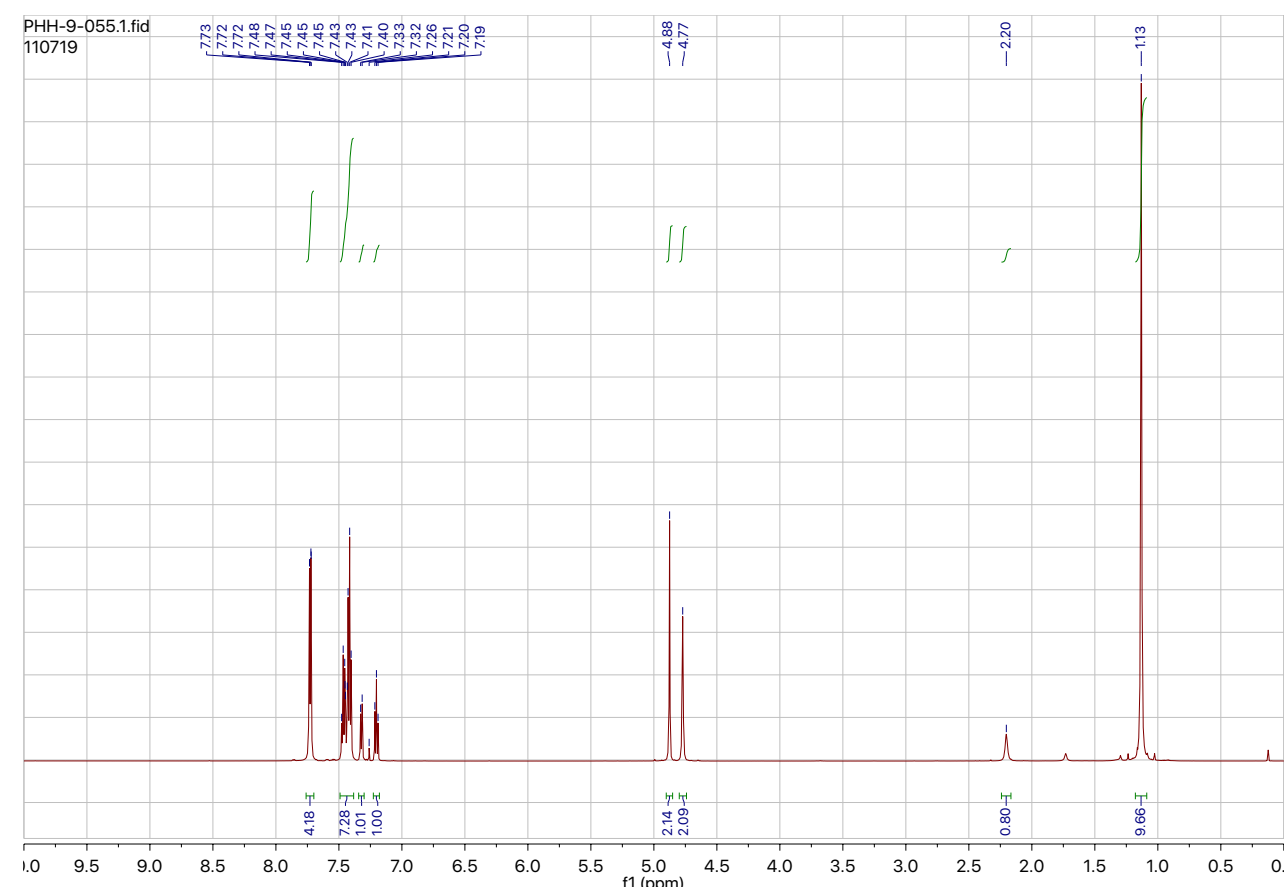

${ }^{1} \mathrm{H}$ NMR spectrum of compound 2 in $\mathrm{CDCl}_{3}$ 
Supporting Information

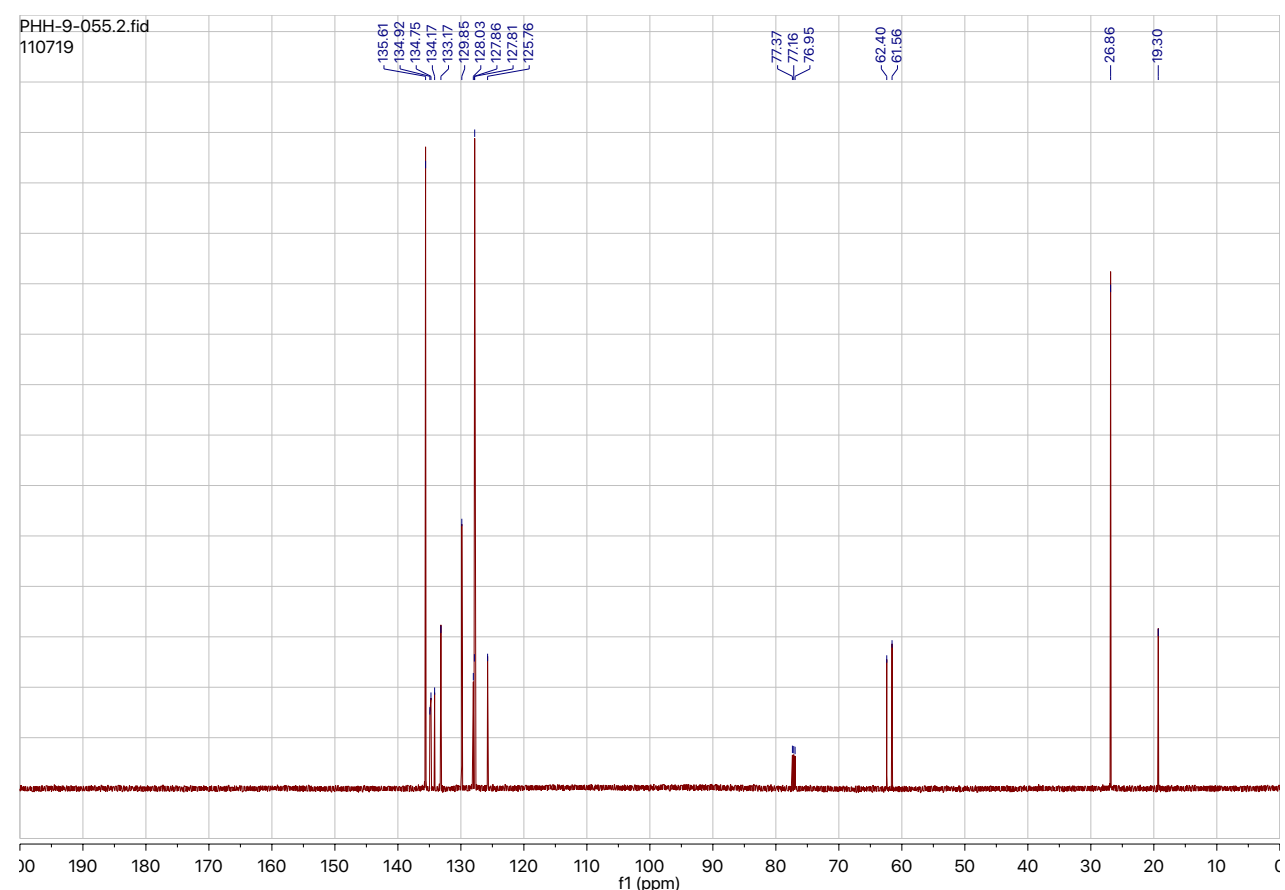

${ }^{13} \mathrm{C}$ NMR spectrum of compound 2 in $\mathrm{CDCl}_{3}$

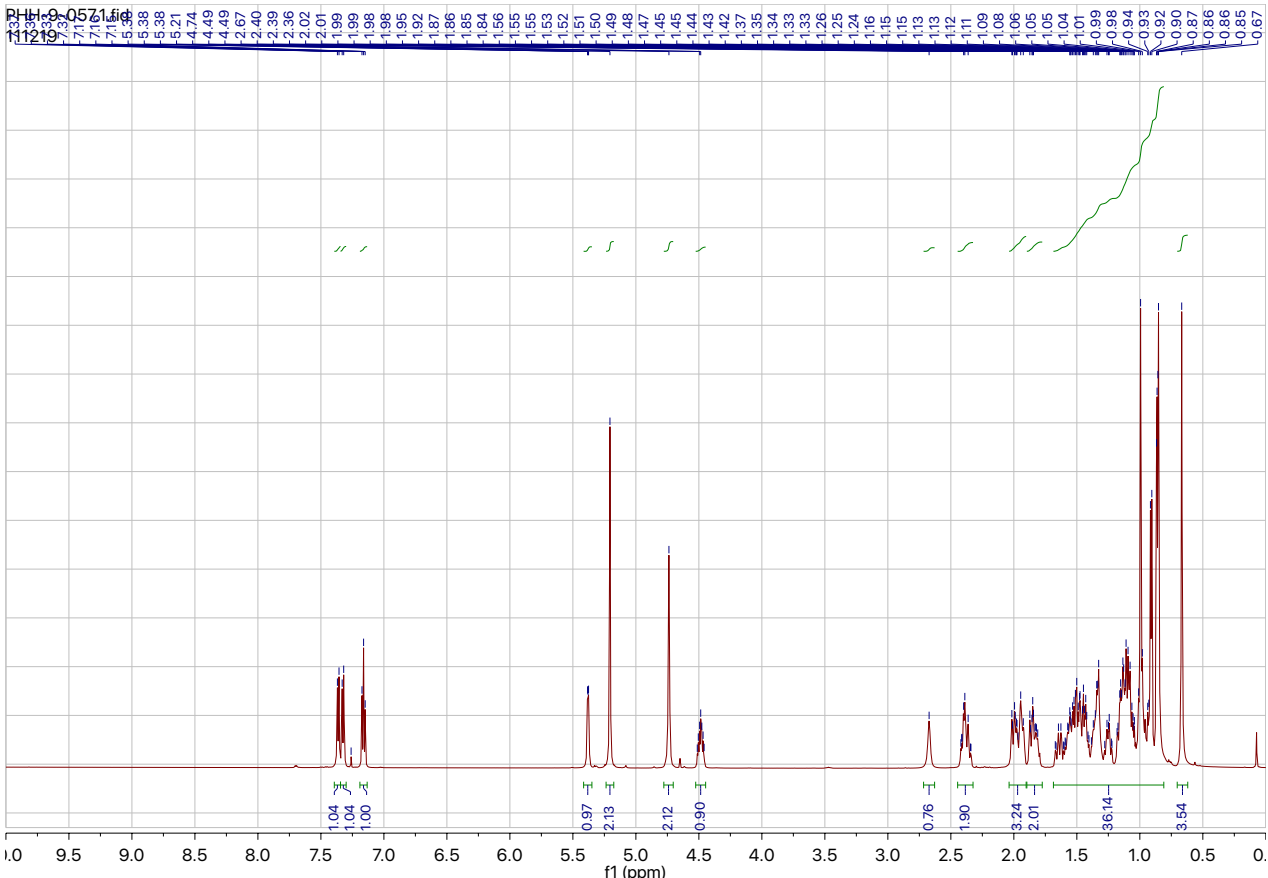

${ }^{1} \mathrm{H}$ NMR spectrum of compound 3 in $\mathrm{CDCl}_{3}$ 
Supporting Information

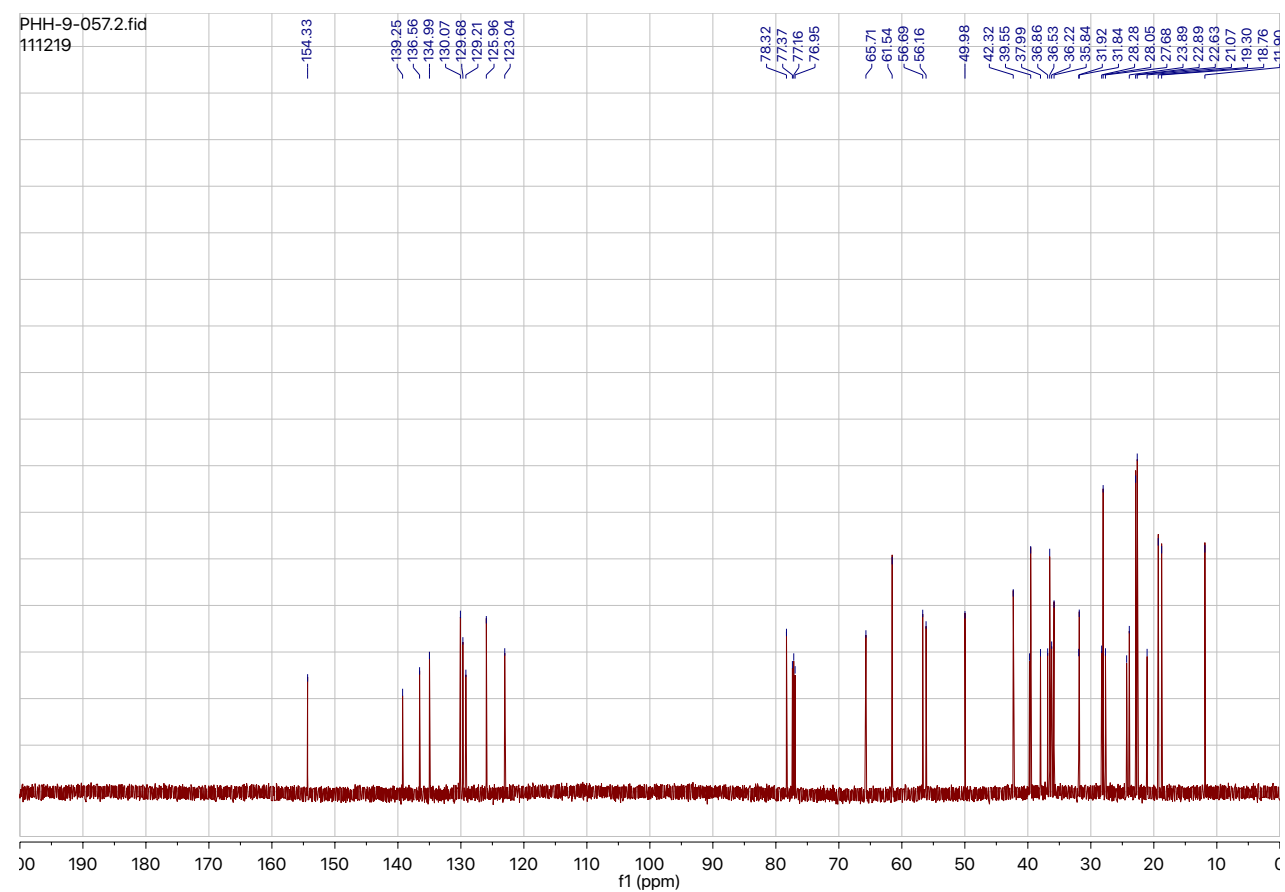

${ }^{13} \mathrm{C}$ NMR spectrum of compound 3 in $\mathrm{CDCl}_{3}$

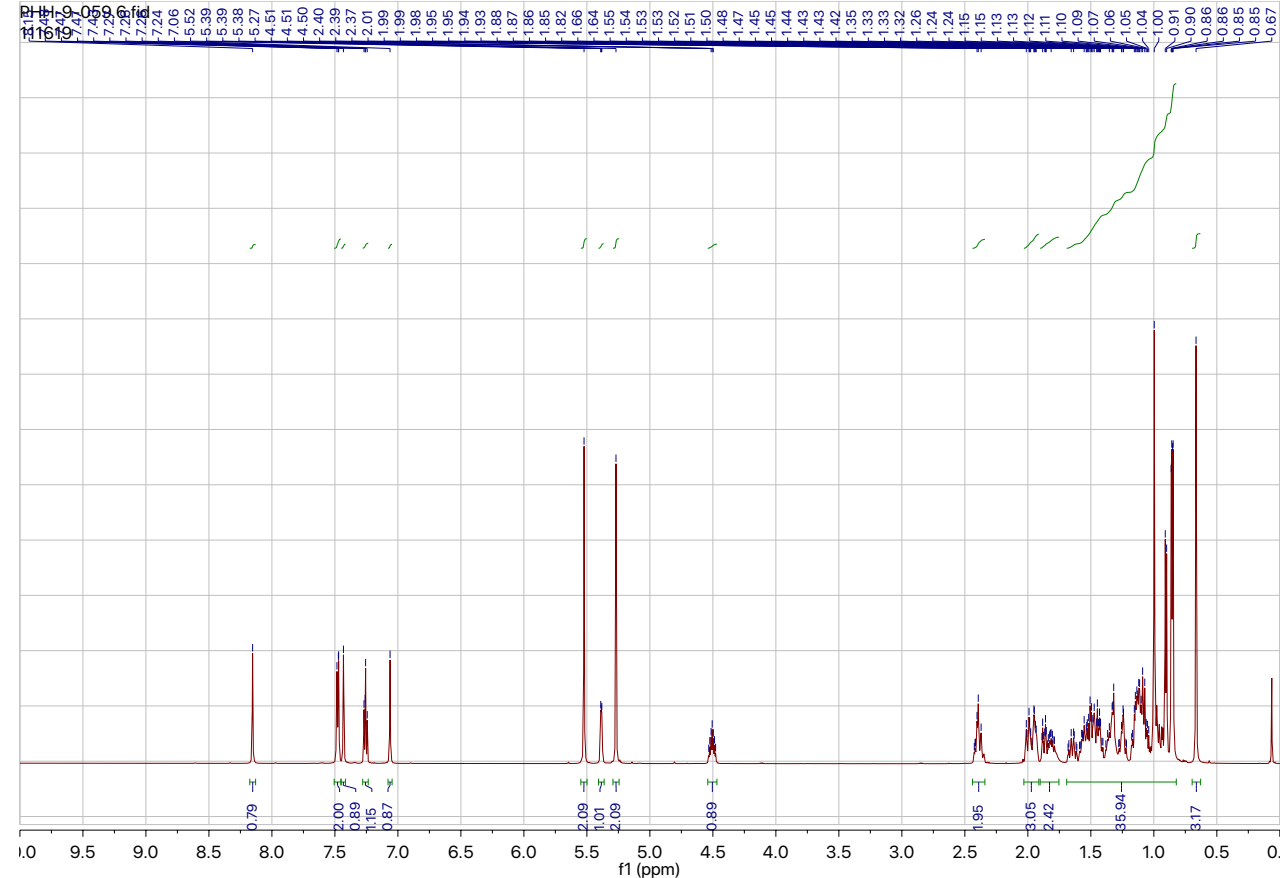

${ }^{1} \mathrm{H}$ NMR spectrum of compound 4 in $\mathrm{CDCl}_{3}$ 
Supporting Information

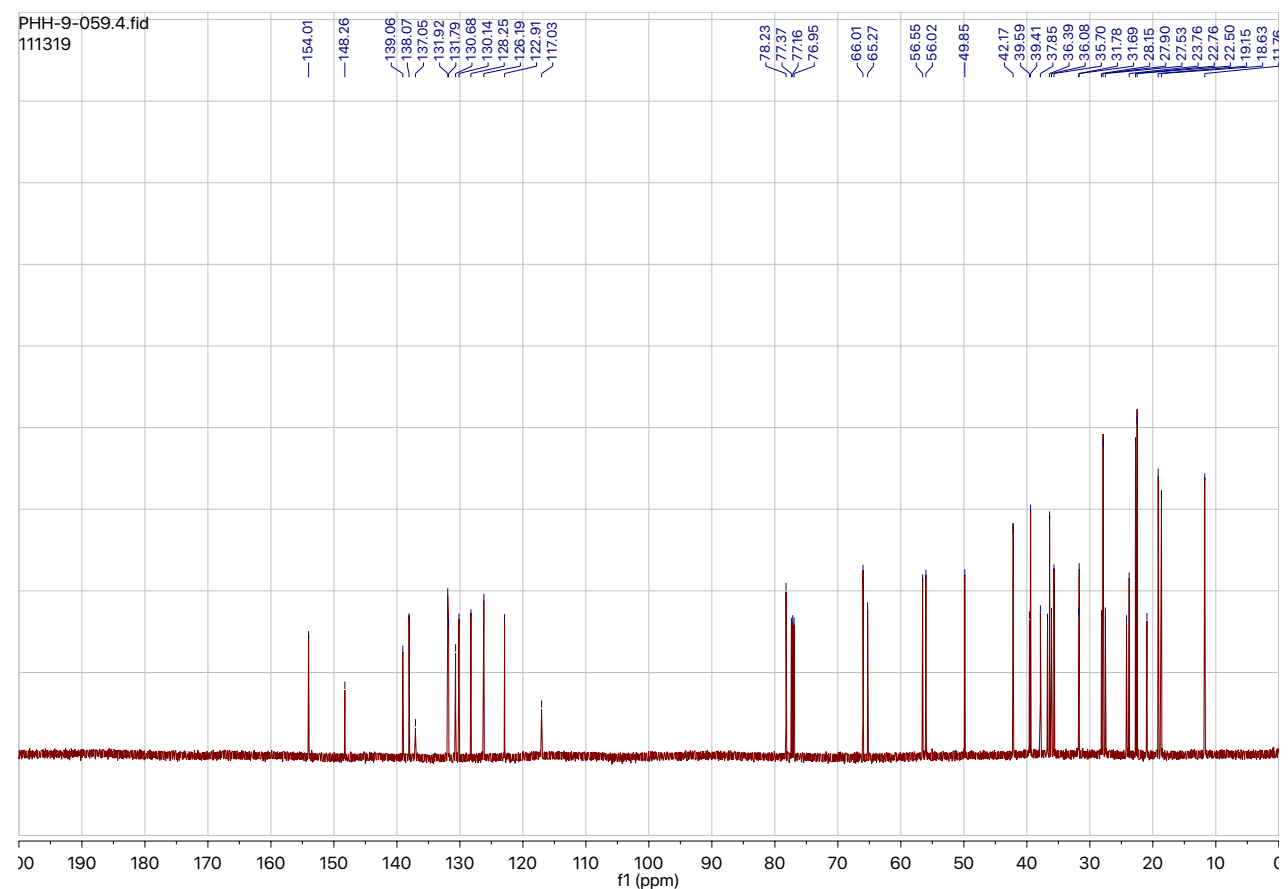

${ }^{13} \mathrm{C}$ NMR spectrum of compound 4 in $\mathrm{CDCl}_{3}$

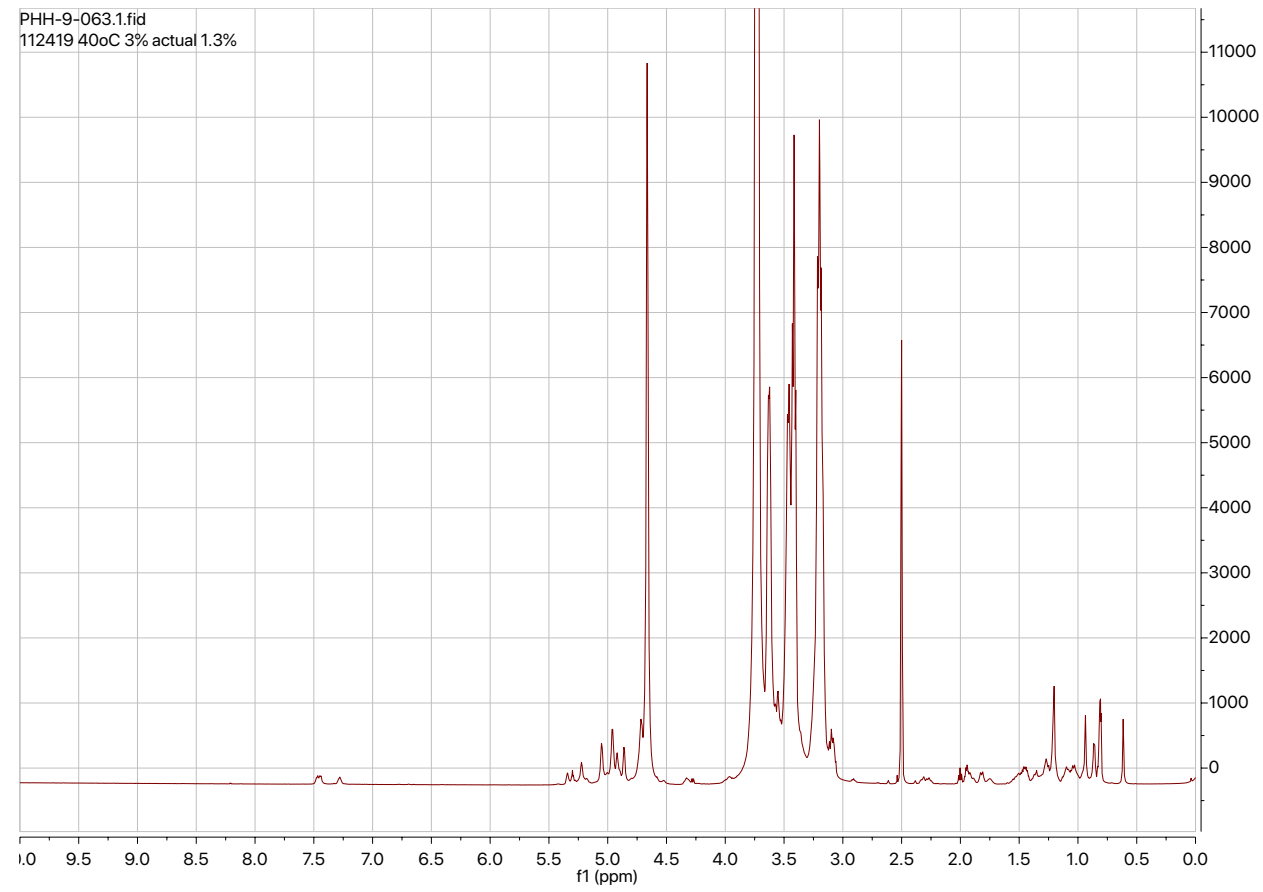

${ }^{1} \mathrm{H}$ NMR spectrum of SC-Dex in $\mathrm{d}_{6}-\mathrm{DMSO} / \mathrm{D}_{2} \mathrm{O}(9: 1)$ 
Supporting Information

12. Reference

(1) Kawasaki, R.; Sasaki, Y.; Akiyoshi, K. Biochem. Biophys. Res. Commun. 2017, 483, 147152. 